\title{
The capital of Karl Marx, Marxism and the Latin American intellectuals: the cases of Mexico and Colombia
}

Miguel Ángel Urrego ${ }^{1}$

\begin{abstract}
:
In the present article we will examine the characteristics of the reading of Karl Marx's The Capital in Latin America, focusing specially in the cases of Mexico and Colombia. Initially, we will study the conditions under which the circulation of the concepts of socialism and communism took place in the middle of the 19th century and how that was followed, decades later, by one of the first translations of the first volume of The Capital to Castilian. Despite these two circumstances, the appropriation of Karl Marx's thinking had serious limitations due to the predominance of conservative and even overtly anti-communist conceptions. Later, due to diverse factors, among which we must mention the Spanish exile, it was possible to translate the three volumes of The Capital, which gave rise to a great variety of readings of this work generating a multitude of debates that stimulated the development of the social sciences and the humanities.
\end{abstract}

Key words: The Capital; Marx- Latin America; Marxism- Latin America; intellectuals - Latin America.

\section{O capital de Karl Marx, o Marxismo e os Intelectuais latino- americanos: os casos do México e da Colômbia}

\section{Resumo:}

No presente artigo, examinaremos as características da leitura d'O capital de Karl Marx na América Latina, focando especialmente nos casos do México e da Colômbia. Inicialmente, estudaremos as condições sob as quais a circulação dos conceitos de socialismo e comunismo ocorreu, em meados do século XIX, e como, décadas depois, houve uma das primeiras traduções do primeiro volume d'O capital para o castelhano. Apesar dessas circunstâncias, a apropriação do pensamento de Karl Marx teve sérias limitações devido à predominância de concepções conservadoras e até abertamente anticomunistas. Mais tarde, devido a diversos fatores, entre os quais devemos mencionar o exílio espanhol, foi possível traduzir os três volumes d'O capital, o que deu origem a uma grande variedade de leituras deste trabalho gerando uma multiplicidade de debates que estimularam o desenvolvimento das ciências sociais e humanas.

1 Doutor, pesquisador do Instituto de Investigaciones Filosóficas Luis Villoro de la Universidad Michoacana de San Nicolás de Hidalgo, México. E-mail: mangelurrego@gmail.com. 
Palavras-chave: O capital; utopia social; marxismo - América Latina; intelectuais - América Latina.

In the present article we will examine the impact that the circulation of The Capital by Karl Marx had in Latin America, although we will concentrate specially in the cases of Mexico and Colombia. We have considered these two cases because they represent the extreme situations in which the circulation of Marx's work took place, since in Mexico there was a favorable cultural environment while in Colombia the conservative domain prevented its diffusion. However in the countries there was a significant theoretical reflection from the reading of The Capital. We will initially study the utopian translations of the XIX century to explain the concepts of socialism and communism. Secondly, we will focus on some of the features that the circulation of Marxism and Marx's thinking had in Latin America. Finally, we will privilege the case of the translation of The Capital to Castilian, and comment on some examples of the way in which this text stimulated some important debates of Latin-American social sciences.

\section{Social utopias: socialism, communism and Marxism in Latin America}

Traditionally, it has been thought that the presence of Marx in Latin America is explained with the founding of the Communist parties or in the reading in Spanish of the work of the German thinker. Nevertheless, this point of view is not adequate. From the beginning of the XIX century the spreading of notions such as socialism, communism, and even Marxism are known in Latin America, and of course in Mexico and Colombia, these tendencies obviously are assumed in a unique way and without the connotations that these concepts have today. Most of these tendencies were fed by what has been denominated social utopias and that have had a long tradition in ways of thinking and literature, for the case we are interested in, this tradition was consolidated and stimulated the formation of what is denominated firts socialism, this is to say, projects that were founded in cooperativism and equality, many of them, Christian in origin, about a fairer social order.

In Mexico Carlos Illades has extensively researched the circulation of socialist authors in the mid-nineteenth century and in the case of Colombia we can find several important studies that show this same circumstance. For Argentina Horacio Tarcus made a reconstruction of the first steps of social utopias, in Mexico, Carlos Illades has widely researched 
the topic, and in the case of Colombia, we find several important studies. ${ }^{2}$ There are several reasons for this fact. In the first place, we must point out that in the XIX century a series of circumstances occurred which privileged the circulation of new concepts: since the independence there existed an ample use of radicalized political language in which common notions of liberal, radical thinking was used to communicate with the people. In second place, the ascent of Democratic Societies and the government of José María Melo, that for some may be catalogued as "socialist", stimulated the radical position of the Colombian artisans. Finally, we must mention that during the XIX century there existed an ample search for ideas and authors who represented the political Avant-guard, and this was not far from the circulation of ideas that at the same time were the trend in Europe. Carlos Illades explains the influence of Víctor Considerant in Mariano Otero, who in the Mexican state of Jalisco made possible the translation of the French utopian and disciple of Fourier from 1850 and even published in 1842 a book based on the application of the ideas of Considerant. In the same way Illades analyzes the case of Sotero Prieto who comes in contact with the Spanish followers of Fourier and returns to Mexico with a collection of La Phalange, forms socialist groups in Tampico and Guadalajara and collaborates at the end of the forties in various newspapers spreading the new ideas. ${ }^{3}$

Also in Colombia the concepts of social utopia to which we refer were known. The juncture of the history of Colombia where we want to pause is that of the middle of the XIX century, which was characterized by three important events: the government of José Hilario López (18491853), in which the mid-century liberal reforms were applied, as the freedom of slaves; the creation of the Artisan Democratic Society, popular groups with a social equality message; and the goverment of José María Melo (April 7, 1854), which was supported by the artisans of Bogota and much of the country, who governed with proposals of social reform until December 4.4

2 Paradoxically the studies related to official versions of Marxism, those coming from PC o Cuba, start from the consideration that Marxism begins with the founding of Communist Parties and little attention is given to the thinkers of the XIX century, see as example (GUADARRAMA, 1999, pp. 1-72). A proposal that rescues the first steps to socialism in (TARCUS, 2016) and (ILLADES, 2008).

3 Carlos Illades studies the early circulation of the first socialists in (ILLADES, 2008 and 2018).

4 Political myth that conservatives built was that López reached power thanks to the intimidation of the artisan's daggers against the voters. A tale that the figures of the civil war which unleashed after Melo's coup in (ORTIZ, 1855). The conservatism instituted the idea that the government of Melo and the artisans was a "coup" or "dictatorship", see the folleto La revolución. Orijen, progresos fines $i$ estado actual de la revolución democrática, que se prepara en esta ciudad. 
Several examples of the circulation of concepts of socialism and communism can be found in Colombia since the late forties. 5 On January 29, 1852, for example, a newspaper was published in Bogota titled The Socialist. The friend of the people, with the support of military leader José María Obando and the government of López, what is interesting is that in this moment the term "communism" became widely used:

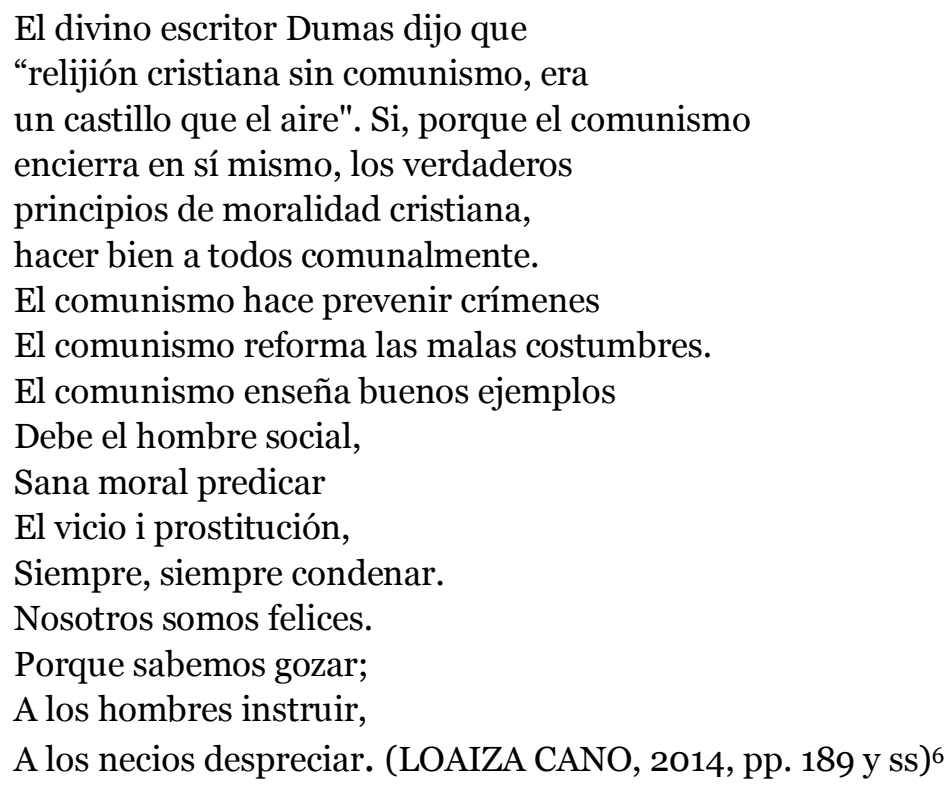

In the same year a work signed by Carlos Mazade dated in Paris May 15, 1852, circulated. It was printed in Bogota and it analyzed the possibilities of socialism for the countries of South America. Besides anticipating that Panama would end up being part of The United States, is that he wrote about the limitations of socialism given the scarce control of the existing territory of New Granada (Colombia) and the population size, besides other factors. Nevertheless, it identified all types of excesses of the radicalized people who protested in all the country with the actions of the Democratic Societies and socialism, with the clear intention of discrediting them (MAZADE, 1852). This posture was used to justify the strong repression that was unleashed against the Democratic Societies and the artisans who supported Melo in Bogota. In effect, liberals and

5 The circulation of the concepts of socialism and communism is studied in the article "A ghost crosses the Colombian Andes: socialism and communism in the nineteenth century" to be published in 2019 in the Archives Magazine in Argentina.

${ }^{6}$ El socialista. El amigo del pueblo (Bogotá: 29 de enero de 1852), p. 1. "Divine writer Dumas said that/ "christian religion without communism, was/ a castle in the air". Yes, because communism/ holds within itself, the true/ principles of Christian morality,/ do good to all communally./Communism helps prevent crimes/Communism reforms bad habits./Communism teaches good examples/The social man should,/Healthy moral preach/Vice and prostitution,/Always, always condemn./We are happy./Because we know how to enjoy;/Teaching the men,/Despising the stubborn." (LOAIZA CANO, 2014, pp. 189 y ss). 
conservatives became military allies and unleashed a bloody repression to crush the radicalized people, resulting in the exile of many to hot jails in the Caribbean.

In another text written to assess the advance of socialism in South America a ferocious criticism is developed toward Lopez' project and socialism and a defense of Catholicism, we quote the document to have the necessary elements to understand what was defined as socialism back then, the author of the document sustains:

Creemos que la cuestion social que ajita actualmente la América i la Europa, puede enunciarse en estos breves términos: ¿Son los principios de la relijion cristiana los mejor calculados para fundar sobre ellos la sociedad? Los que resuelven esta cuestion negativamente se llaman socialistas. Esta secta tiene dos escuelas: la una pretende destruir todo lo que existe, sin proponer cosa alguna en su lugar, para que del desórden sumo, salga el bien, como el mundo salió, en concepto de ellos, del caos-es decir, por "casualidad: la otra pretende, que desaparezcan la familia, la relijion cristiana i la propiedad, para sustituir al matrimonio la promiscuidad de las mujeres; a los cuidados paternos, los de un poder comun que crie, cuide $\mathrm{i}$ eduque los niños; a la propiedad, la administracion de los bienes por un poder tambien comun, que reparla entre los hombres lo necesario para satisfacer sus necesidades; i que no permita a nadie gozar de lo superfluo, mientras todos no tengan lo necesario.

Hai, pues, dos sectas de socialistas: 1. Socialistas destructores. 2. Socialistas visionarios. El centro de estas dos sectas está en Francia, pero sus ajentes andan por todo el mundo, i en todas partes aparecen asumiendo diferentes formas, segun que conviene al progreso de sus doctrinas. La maña, la astucia, la hipocresía, la violencia, la adulacion, la calumnia, la incredulidad, hasta la predicacion del cristianismo-todo les sirve, de todo echan mano. Los socialistas cuentan ademas con muchos instrumentos, que estan trabajando para ellos, i no lo saben, como el buen hombre de Moliére, que al cabo de muchos años de estar escribiendo, no sabia que estaba escribiendo prosa.

Ambas sectas socialistas están de acuerdo en que la familia i la propiedad son inconvenientes sociales que deben removerse; i como precisa e indispensable consecuencia, sostienen que el cristianismo no consulta las necesidades, ni resuelve los problemas sociales (ELDROPEITO, 1852, pp. 6 y 7 ). 7

\footnotetext{
7 "We believe that the social issue that currently agitates America and/Europe, can be enunciated in these brief terms: Are the principles of/The Christian religion the best calculated to found upon them the society?/Those who resolve this matter negatively are called socialists. This/ sect has two schools: one pretends to destroy all that exists, without proposing/ anything in its place, so that from extreme disorder, come out good,/as the world came out, in their concept, from the chaos - that is to say, by "chance":/ the other pretends, that family, Christian religion and property disappear,/to
} 
As Eric Hobsbawm and E.P. Thompson have demonstrated, the social utopias were frequently elaborated by men and women from diverse Churches throughout the history of Christianism and Protestantism, and in fact the League of the Just, immediate precedent of the I International, and had as motto "All men are brothers" and asserted the legacy of Jesus Christ (HOBSBWAM, 1964 y THOMPSON, 1989). So that it is not about an anomaly but something that had already existed for various centuries and surely had to do with the difficult life conditions of the rural and urban worlds that Marx describes crudely in The Capital.

But nevertheless, the origin of the term socialism as has been noted by several authors, is attributed to Robert Owen (1830) and the French newspaper Le Globe who used it in the thirty decade, specifically in 1830 and 1832 (PANIAGUA, 2010, p. 13). Engels explained the difference between socialism and communism pointing out in 1847 that the first were looking for political transformations as a result of the action of the educated sectors whereas the communists wanted the radical transformation of society based on the power of the working class (BRAVO, 1971, pp. 58 y 59).

Of course, the transformation of the League of the Just, created in Paris in 1836, to the League of the Communists (June,1847) and the publication on February 21, 1848 of The Communist Manifest by Karl Marx and Fredric Engels gave to the concepts of communism and socialism a new content and clearly differentiated them from the previous ones. In the second half of the nineteenth century there was in Latin America, with greater or lesser clarity, reference to socialism and communism. ${ }^{8}$ So the circulation of such concepts does not seem strange in countries like Colombia, more even when there was a trend to follow and copy all the French influence of the new liberalism, a long tradition of

substitute marriage the promiscuity of women: to paternal/care, to those of a common power that raise, care and educate the children: to /property, the administration of the goods by a common power too,/that distributes among men the necessary to satisfy his needs; and/that he does not allow anyone to enjoy the superfluous, so long as all do not have the necessary./There are then two sects of socialists: 1 . Destructive socialists. 2. Visionary socialists./The center of these two sects is in France, but their agents are/all over the world, and they appear everywhere assuming different forms,/according to what is convenient to the progress of their doctrines. The dexterity, /cunningness, hypocrisy, violence, flattery, slander, disbelief, even the preaching/of Christianism - all serves them, they use everything. The socialists/have besides many instruments, that are working for them,/and they do not know, how the good man Molière, who after many years /of writing, he did not know he was writing prose./Both socialist sects agree that family and property are/social inconveniences that must be removed: and as a precise and indispensable/consequence, they sustain that Christianism does not meet the/needs nor resolves the social problems."

${ }^{8}$ In 1948 was published in Chile, by Santiago de Chile Editorial Universitaria S.A., a commemorative edition marking the centenary of El manifiesto that had 100 numbered copies.

Electronic 
dissident thought prompted by the masonic societies and a radicalism of Democratic Societies. 9 The use of these references explains the existence of a thinker such as Manuel María Madiedo in XIX century Colombia. In fact, although Madiedo is seen by some as a conservative thinker, truth is that in his work he tried to articulate socialism and Christianism in a very particular way (MADIEDO, 1853).

It should be noted that "appropriations", "translations" or reading practices are common, which gave a particular meaning to the political language. That is, there is no copy, submission to Western epistemes or anything similar, because all reading and use of concepts involves passing them through the filter of concrete historical experiences. So those who acted politically with the ideas of the first socialism in Mexico or Colombia did so from an enrichment of the concepts created by Europeans.

\section{Marx and Marxism in Latin America}

Marx and Marxism have a contradictory presence in the continent, while on the one side there was an early translation of The Capital at the end of the XIX century, its appropriation was limited and was not always based in a direct reading of the author, but in various types of booklets. ${ }^{10}$ However, the development of social sciences is due greatly to its ideas. For this, the criticism of Latin-American Marxism by the de-colonials is surprising, for they are terribly ahistorical, because of the lack of knowledge of the authors and in many cases the manipulation of arguments with the clear intention of achieving a self-affirmation of an assumed criticism founded in an apparently radical narcissistic provincialism. ${ }^{11}$

One of the first translations of The Capital to Castilian was done by Argentinian socialist leader Juan B. Justo in 1898, for which he considered the fourth German edition, volume I. ${ }^{12}$ This is not a small fact, but of enormous significance for the political and cultural history, for there was

\footnotetext{
9 About the action of Democratic Societies and their slogans see (AGUILERA y VEGA, 1991).

${ }_{10}$ The impact of Marxism in the 20th century is studied by Michael Löwy (LÖWY, 1980).

11 Enrique Dussel points, correctly in our opinion, that Santiago Castro-Gómez permanently deforms his opponents, and describes the proceeding of the Colombian philosopher as a cartoonish "ape." We can also include in this attitude Ramón Grosfoguel, another spokesman for the decolonials in (CASTRO-GÓMEZ and GROSFOGUEL, 2007) and in the articles by Aníbal Quijano, Edgardo Lander and Grosfoguel published in (SANTOS and MENESES, 2014).

${ }_{12}$ A detailed analysis about the translations to Spanish of El capital by Marx is done by Pedro Ribas. There it was not the first translation to Castilian, but the limitations and virtues are highlighted of the work of Juan B. Justo (RIBAS, 1985, pp. 203 y ss). A detailed list of translations in the text "Traducciones de El capital al castellano" in http://seguiiltuocorsoelasciadirlegenti.blogspot.com.co/2011/10/las-traducciones-de-elcapital-al.html
} 
not a long wait until the translations from Europe arrived and, on the other hand, as in other cases from several philosophers, Latin Americans worked directly at the author, fundamental fact when you consider the problem of the use of a thinker and the history of reading.

A second feature is that at the beginning of the XX century the sectors that identified with Marx and Marxism were generally radicalized liberals or "socialists" who joined the existing organizations, included the Communist Parties, but without having to make great ideological changes or epistemological ruptures. Of course, we are not pointing to the existence of a pure theoretical or political state, but of a minimum agreement among political affinity and theoretical and ideological expressions. Many cases illustrate this procedure, José Ingenieros, for example, was one of the defenders of socialism, but he had an evident positivist and liberal inheritance.

A third aspect to consider is that the reading was not available to all. There existed a very small literate population, the creation of schools of thought has been traditionally difficult, a few people in political organizations were dedicated to study, and the reading of Marx basically developed with the translations to Castilian, therefore, criticism had to wait a couple of decades, despite the merit of Bustos and other intellectuals.

In fourth place, we must consider that the spreading of socialism and communism went through the experience of very particular dissident thought as were anarchism and spiritism. Anarchism of the Flores Magón brothers and the Mexican Political Party (PLM) in Mexico had the important collaboration from the radical trends of The United States; they had several means of communication, being Regeneración the most important one achieving recognition on both sides of the border; it had a cultural project which included literature, theatre and education; and the PLM was one of the precursors of the Mexican Revolution. ${ }^{13}$ With this we want to say that anarchism was at the end of the XIX century and beginnings of the $\mathrm{XX}$ and was more important than socialism and communism. This same circumstance can be found in Argentina where anarchism had considerable force due to migration.

Finally, we must highlight that universities were the spaces where Marx could circulate as a theoretical reference, especially in some faculties as philosophy and economy. However, it is necessary to clarify that the entering of Marx into the universities was not easy, in fact, Horacio Tarcus points that for the Argentinian case, Marxism was developed outside these institutions and even the leftist parties (TARCUS, 1996, pp. 17 y 18). The

13 Claudio Lomnitz makes a detailed analysis of Mexican anarchism, in particular the leadership of the PLM in (LOMNITZ, 2018). 
resistance in Latin America to these currents of thought was very strong and the conservatism was prevailing, in occasions openly anticommunism, denied any possibility of access to Marxism. Besides, in some countries there existed dictatorships that persecuted any dissident thought, university professors disappeared or were forced into exile and the circulation of books was forbidden.

Mexico was the exception where the Revolution stimulated an important group of thinkers that can be placed to the left of the political spectrum; it was one of the few countries that recognized the Russian Revolution almost immediately; there was an educational reform driven by Lázaro Cárdenas, because of the constitutional reform of 1934, which selfdenominated as "socialist"; there existed editorial projects by the communists and the government, which facilitated massive editions of texts as The Manifesto; and Mexico was one of the nations where more North American dissidents and Spanish exiled from the civil war settled. The effect of these events was that the language used in the first half of the XX century had radical tints, there was permanent talk about revolution, socialism, the proletariat, etc., in fact, the Revolutionary Institutional Party (PRI) was created (whose mission was defined as the "continuity" of the "revolution") and there was certain ease in the access to some classic Marxism authors (RIVERA MIR, 2017, pp. $171 \mathrm{y} \mathrm{ss).} \mathrm{However,} \mathrm{the} \mathrm{arrival}$ of the exiled was determinant because it accentuated the relations among the lefts of The United States and Mexico and in the thirties the Spanish exiled substantially changed the relation with Marx and The Capital. In fact, the arrival in 1939 of exiled intellectuals as Adolfo Sánchez Vázquez and Wenceslao Roces, facilitated the programming of seminars and publications that had a clear presence of Marx, which contributed the spreading of his thought in a university as the UNAM. ${ }^{14}$

Henceforth, academics could guide their seminars toward the reading of Marx, they organized diverse types of events and finally started publishing books. Sánchez Vázquez for example made known in 1965 The aesthetic theories of Marx and in 1967 The philosophy of praxis. ${ }^{15}$ What is interesting is that the first text was immediately commented in Colombia through a review that appears with the edition date of 1968, elaborated by Miryam de Aragón and published in the philosophy magazine Ideas and Values (DE ARAGÓN, 1968, pp. 91 y 92). Sánchez Vázquez gave a conference in which he gave his personal vision about the beginning of

${ }_{14}$ An approach to the author we commented is the compilation of a series of reflections surrounding the work of Sánchez Vázquez that Gabriel Vargas Lozano does (VARGAS LOZANO, 1995) and a more recent book is the Stefan Gandler (GANDLER, 2007).

15 (SÁNCHEZ VÁZQUEZ, 1965) whose hypothesis was anticipated in the article "Ideas estéticas en los manuscritos económicos-filosóficos de Marx" (SÁNCHEZ VÁZQUEZ, 1961 Y 1967). 
Marxist criticism, he saw the presence of Marxism in Latin America starting with the translations, as the one by Juan B. Justo; the formation of political organizations, he claims the creation of the Argentinian Socialist Party (1895); and comments on the few apparent references of Marx in Latin America, as the polemic opinions about Simón Bolívar. ${ }^{16}$

In the National University of Colombia the renowned intellectual Antonio García Nossa gave rise in 1945 to the Economical Science Institute that was the basis for the creation of the Economics program in 1952, although it was initially part of the Law Faculty (FACULTAD DE CIENCIAS ECONÓMICAS, 2014, p. 9).17 At first, Marx appears in the course of general history of economic thought, but by the sixties, due to the founding of the Sociology Faculty (1962); to the irruption of the New History; the publishing of the Colombian History and Culture Yearbook(1962); to the presence of a new type of intellectuals, among who were Orlando Fals Borda, Darío Mesa and Camilo Torres Restrepo; and to a greater leftist political presence in the midst of each strengthening student movement, Marx and The Capital appear with more presence. ${ }^{18}$ For this reason it is not odd that for the following decade there were seminars about The Capital in various faculties of the National or District Universities.

It is necessary, of course to make a periodization of the circulation of Marx in Latin America, because It has not always been the same. Horacio arcus, for example, does an ample reconstruction of Marx's and Marxism's first steps in Argentina starting in the decade of the seventies in the XIX century and finds very significant facts as the existence of Paris commune exiled, the correspondence between Raymond Wilmart and Marx (1873), the founding of the first socialist clubs, the organizational activities of the German immigrants, the publication of articles, books and pamphlets and the transit of some intellectuals to Marxism at the end of the XIX century (TARCUS, 2007).

Nevertheless, we can say that Wenceslao Roces' translation of the readings was marginal, done by a few followers tied to leftist organizations and critical intellectuals. This translation, the Spanish exile, the increase of travelers and the emergence of the New Left in the sixties opens an epoch of boom in which the diverse types of Marxism became very popular, as happened with Gramsci or Althusser, to mention two cases. ${ }^{19}$ Then there

16 Adolfo Sánchez Vázquez, Conferencia, "El marxismo en América Latina" en Dialéctica, $\mathrm{n}^{\mathrm{o}} 19,1988$, in <http://marxismoyrevolucion.org/wp-content/uploads/2016/o6/Elmarxismo-en-Am\%C3\%A9rica-Latina.pdf $>$.

17 In: <http://www.pregrado.unal.edu.co/docs/pep/pep_2_24.pdf $>$.

${ }_{18}$ Changes in the intellectual world and in the Colombian social sciences in the $1960 \mathrm{~s}$ in (ZULETA PARDO, 2011 and URREGO 1997).

${ }^{19}$ It is necessary to note that not always Gramsci o Althusser were well accepted by the communist officials. In fact, in Argentina la introduction of Gramsci generated a strong 
is a stage of decadence generated by the centrality of the leftist military option - the guerillas -, which reduced the importance of reflexive theory and was aggravated with the dictatorships and further on with the disintegration of the USSR, the margination of prestigious intellectuals of the PC and the impact of the debate about the end of ideologies, and of course, some intellectual trends of marked anti-communism, as the denominated postmodernism, and today the Decolonial Turn. However, we attended to a resurgence of Marx and the reading of The Capital promoted by four significant events: the neoliberal globalization crisis, the publication of a series of works where Marx's ideas were revalued, the centenary of the Russian Revolution, and the commemoration of the 150 years of the edition of the first volume of The Capital.

\section{Translations of Capital and Development of Social Sciences in Mexico and Colombia}

The growth of editorial activity due to the increase of magazines and publications, the strengthening of the public university and a boom period of the social and worker movement facilitated the dissemination of Marx's writing after the second postwar. Let us remember that the Spanish exile was characterized by the creation of important publishing houses in Mexico, as Era (1960), and naturally a significant number of institutions tied to culture, among them, El Colegio de Mexico, the philosophical magazine Diánoia (founded by exiled Eduardo Nicol and Eduardo García Máynez in 1955) and many more institutions (PAGNI, 2011).20 There are various references to the introduction of Marxism and Marx in Mexico, as is the classical study of Harry Bernstein (BERSTEIN, 1958), ${ }^{21}$ but as in the Colombian case since the middle of the of the XIX century theoretical postures close to first socialism circulated creating a conductive environment for Marx's ideas. ${ }^{22}$ Great differences as the ones we have noted have existed between Colombia and Mexico, especially by the force

struggle which ended with the expulsion of the Communist Party from those who looked for the theoretical renovation. On the way the Italian Marxist was read, see (ARICÓ, 2005)

2o María Garone Gravier gived the following list de editorials linked to Spanish exile in México: Unión Tipográfica Editorial Hispano Americana (UTEHA), Proa, Centauro, Costa-Amic editor, Diógenes, Edición y Distribución Ibero Americana de Publicaciones, S. A. (EDIAPSA), Ediciones Cuadernos Americanos, Oasis, Xóchitl, Edicions Catalanes, Edicions Catalònia, España Errante, Finisterre, Leyenda, Minerva, Séneca y Quetzal.

${ }^{21}$ Harry Bernstein argues that Marxism spread in Mexico after the Russian revolution in <http://codex.colmex.mx:8991/exlibris/aleph/a18_1/apache_media/1YLNLR313XN1QY QKLTB3DCIDM1UXBP.pdf $>$. This same hypothesis is retaken by Carlos Illades in (ILLADES, 2018)

22 There are various works that generally analyze Marx's acceptance in Latin America and they stop in what is called the "disagreements" of Marx with Latin America, as an example see (BOSTEEELS, 2012). 
of the anarchist movement, the outbreak of the Revolution and the closeness of critical intellectuals to their peers in The United States and Europe. Let's see now the importance of the complete translation of Capital and its repercussions in the countries studied. In Mexico, the work of Wenceslao Roces was determinant for various generations of scholars, because it democratized the access to Marx and facilitated its use in the university environment. Roces had been member of the Central Committee of the Communist Party in Spain and developed an important activity as translator and diffuser of Marxist authors, precisely because of his activities, he had to emigrate (March 30, 1941) and once installed in Mexico City, he connected to the Economic Cultural Fund. 23

The idea of creating the Economic Cultural Fund was thanks to the prominent intellectual Daniel Cosío Villegas (1934) and had as a purpose resolve the demand for texts in the economy faculties. However, time later it expanded and strengthened as a state business to encourage reading. The formal economy studies had begun in 1929 in what is today the UNAM, though as part of the National School of Jurisprudence. In 1935 it became National School of Economy, being Enrique González Aparicio its first director. Initially there was not a specific seminar on Marx in its study plans, from what we have consulted, in 1946 it contemplated only for the second year a "general theory of capitalist development" and two courses about "the history of economic thinking". 24

There is a controversy surrounding the problems of translation to Castilian of the different versions of The Capital. The mistakes from the first complete edition by Wenceslao Roces have been pointed out by several authors. Equally, it has been commented by various scholars, that the most accurate translation is the one done by Siglo XXI Publishers. Nonetheless, for others it is the one made by Manuel Sacristán for publishing house Grijalbo. This topic, though very important, will not be dealt with in the present article since it is not its purpose. Neither we want to repeat what has been claimed by others, so we will remit to the direct sources, those who analyze the difficulties of certain concepts and phrases used by Marx. ${ }^{25}$ It is enough to highlight the link between exile, the Economic Cultural Fund and university activities.

23 Information about Roces' life in <http://portal.uc3m.es/portal/page/portal/instituto_figuerola/programas/phu/dicciona riodecatedraticos/lcatedraticos/rsuarez $>$. Alejandro Estrella, "El exilio y la filosofía marxista. El caso de Wenceslao Roses" was published, en (ILLADES, 2007, pp. 205 y ss). 24 "Plan de estudios de la Escuela Nacional de Economía” in El Trimestre Económico, Vol. 13, No. 49, 1, (México, abril-junio de 1946), pp. 175-177, in <https://www.jstor.org/stable/20854819?seq=1\#page_scan_tab_contents $>$.

25 About this ítem see the comment of Rolando Astarita in <https://rolandoastarita.blog/2012/o9/13/traducciones-de-el-capital-y-un-error-ensiglo-xxi $/ \geq$. See the comments of Pedro Scaron about the different versions of the initial study of the XXI century translation in Karl Marx (SCARON, 2017). Finally Horacio 
When addressing the topic of how The Capital has been read it seems unfair to suppose that we can mention all the cases or even detain ourselves in one author or problem, we would say that we will only present a selection, accompanied by a few cases of a brief comment and basic references. The complete listing could include the Theology of Liberation: the theory of dependence; the readings from different variants of Marxism up to now, the anthropology or sociology; the debate surrounding the concepts of manners of production and Social and Economic Formation in Latin America; the readings of Marx by intellectuals such as Bolívar Echeverría or Enrique Dussel; and the reflections in Colombia by academics such as Estanislao Zuleta or Rubén Jaramillo Vélez. However, we will only take some examples due to the introductory nature of this article.

From the vast Mexican experience, which includes those born in this country and to the exiled who arrived, we would like to briefly comment the cases of Bolívar Echeverría and Enrique Dussel, for they allow us to see both aspects already mentioned. As in the other cases we worked with we do not want to say that they are the only ones who rigorously studied The Capital and the thinking of Marx. On the contrary, there are several anthologies that place the boom of Marxism at the end of the sixties and propose a vast consideration of topics, among which stands out the relationship between the monopolies and the State, the nine currents of interpretation, the State and power, etcetera (MARINI and MILLÁN, 1995).

Of Dussel we recognize that he is one of the few that reads in the original language, he has dedicated over two decades to the readings of Marx and has ample work about the conceptual and methodological that derive from The Capital and the Grundrisse, a trajectory that very few in the world can claim. The record of Dussel has been mentioned by several authors, especially those who have followed his thought for decades, so we do not believe it necessary to repeat it (BAUTISTA, 2014). What we do highlight is that the concepts and method of The Capital feed his unique way of keeping alive the Philosophy of Liberation, and for this he focuses on: a first general explanation to Marx's method (1985) and The Grundrisse method; the study of the manuscripts from 1861 to 1863 that are between The Capital and The Grundrisse, first analysis known about such texts; in Toward an unknown Marx in the genesis of the different

Tarcus writes an article about Castilian translations (TARCUS, 2017). A work of exegesis on the most known translations in Victoria Correa Merlassimo, she study three different spanish traslations of Karl Marx's Das Kapital: Juan B. Justo (1898), Wenceslao Roces (1946), Pedro Scaron (1975)" electronic version in <https://eet.pixelonline.org/files/research_papers/SP/Analysis\%20of\%20Three\%2oDifferent\%20Spanish \%20Translations\%20of\%20Karl\%20Marx_S\%20Das\%20Kapital.pdf>. 
volumes and chapters The Capital; considers few known aspects as the theological metaphors that Marx uses; studies the reformulation of the concept of modernity and the origin of The Capital and The Grundrisse; to explore the importance of the notion of a living work; and fin ally to investigate the ethical implications of works as The Capital (DUSSEL, 1985, 1985b, 1988, 1990, 1993, 2008).

Bolívar Echeverría is a thinker who continues to generate questions despite his death in 2010, for his work finds continuity in a varied group of academics. Héctor García in his doctoral thesis considers that the work of Echeverría draws from the reflection about Marx's notion of capitalism. Equally Echeverría is important for conducting a seminar about The Capital for six years, explaining Marx's method and reformulating the concept of modernity for Latin America through the notion of Ethos Barroco. ${ }^{26}$ We now see the Colombian case.

At the end of the fifties a great rupture with the dominant conservative thought in Colombia was produced, many were the symptoms of this awakening: the painting of Debora Arango; the creation of Mito magazine; the foundation of Eco magazine (qualified as the main space of "transgression and cultural diffusion" and in charge of spreading the German philosophy, particularly Critical Theory); The Nothing Movement; and the emergence of the New Left, one contrary to the Communist Party. Thanks to the rupture environment of the end of the fifties and beginning of the sixties, there emerged a series of intellectuals who tried a great rupture from the thinking within Marxism, but without the dogmatism of the Colombian communists and looking for new ways in the articulation of, for example, the thinkers of the suspicion (Marx, Nietzsche and Freud). Such was the case of the Estrategia group which incarnated the search for a new way in a political level as well as a theoretical one. The publication of the magazine Estrategia gave an account of this approach and the work of conferences and writings of the second search. Within this small group we want to mention Estanislao Zuleta, not because he was the only one to work on Marx, but to give an example of what has been pointed out. 27

The reflections of Zuleta about Marx's work and The Capital in particular, started at the beginning of the sixties. In 1963 a "comment to the General introduction to the criticism of political economy" by Marx

${ }^{26}$ Héctor García Cornejo analyzes the relation between Marx and Bolívar Echeverría in his doctoral thesis in philosophy that will sustain in January, 2018 and which he used for being member of his sinodal table, (GARCÍA CORNEJO, 2018).

${ }^{27}$ We do not pretend to reduce the options of Colombian thought renovation to the Estrategia group or to Zuleta, for we recognize a great variety of critical intellectuals that for lack of space we did not consider in the present text, among them Rafael Gutiérrez Girardot, Mario Arrubla, Diego Montaña Cuellar, Rubén Jaramillo Vélez, etcétera. 
was known, and it was revised in later years (for example, in 1972). ${ }^{28}$ For some critics these debates are precisely the starting point of the most rigorous Marxist criticism in Colombia, affirmation we do not agree with for what has been previously exposed. Supelano-Gross indicates that up to the end of the sixties Marxism was: "booklets and pamphlets that Russia had started to issue in the thirties, and it is not until the arrival of men like Estanislao Zuleta, Mario Arruba and Jorge Orlando Melo, who start the serious analysis and studies about Marxism in Colombia, although with radical criticism" ${ }^{29}$

However, if we consider as an indicator of the presence of the Marxist currents in Colombia, the university booklets and the anthologies, we conclude that Marxist followers have been erased from the accounts about critical thinking. The recent selection of writings for the Anthology of contemporary Colombian critical thought, made by Victor Manuel Moncayo, who had written important texts in the seventies, and includes a set of very known names, some of which can be catalogued as critics, but inexplicably various writers and journalists are considered, even Nobel García Márquez and do not include thinkers who because of their significant work for social sciences, their militancy, or having written leftist literature, should be, among those who write about the production mode as Anteo Quimbaya (Jaime Cuellar), Francisco Posada; the first works of Salomón Kalmanovitz; academics of a long trajectory as Rubén Jaramillo Vélez (who spread the Frankfurt School and Marxism in Colombia); Rafael Gutiérrez Girardot (one of the most important intellectuals of the XX century and amply known in Mexico and several European countries); or members of the Communist Party intellectual team, from Trotskyism or Maoism. $3^{\circ}$ Therefore it is necessary to refer to a series of debates that are important in the development of social sciences and that were proposed to read from the Colombian reality to Marx.

The debate regarding the manner of colonial production in Latin America generated an important political and academic struggle for almost two decades. Initially we should note that the debate took place around the contents of the concept, which included the controversy about how Marx understood it; the manner of Asian production; the transition from feudalism to capitalism; and the political implications of this characterization, for the type of revolution that was needed in Latin

\footnotetext{
28 The main reflections of Zuleta about Marx are found compiled in the text Ensayos sobre Marx (ZULETA, 1987).

${ }_{29}$ Claudia Supelano-Gross quoted by Jairo Gallo Acosta, "El retorno de lo reprimido en Colombia: marxismo y psicoanálisis" in (SUPELANO-GROSS, 2016, pp. 213-20).

3о The Communist Party establishes a listing of contributions to culture in the artícle "El Partido Comunista Colombiano y la cultura" in Voz Digital (Bogotá, 15 julio, 2016), <http://semanariovoz.com/el-partido-comunista-colombiano-y-la-cultura/ > .
} 
America depended on it. $3^{1}$ The divergence point was developed in the light of Marx's reading and the distinction between the way it is produced and the circulation of merchandise. In a more specific way the first responded that the market did not matter but the specific conditions of production and for this Latin America was feudal or semi-feudal. The second explained that the continent since the arrival of the Spanish took part in the market capitalist nets and for this it was capitalist.

The controversy about what feature predominated in Latin America during the colony was expanded to what was happening in the period before the arrival of the Spanish, especially because there was a need to explain the complexity of the Inca, Maya, or Mexica social organization, generating long debates. A very known thesis showing the complexity of pre-Hispanic societies was the "Inca Communist State" and also the "Inca Socialist State". The first thesis was presented by Víctor Raúl Haya de la Torre and the second was by historian Luis E. Valcárcel, but naturally the most elaborate reflection on the subject was proposed by José Carlos Mariátegui. ${ }^{2}$ The disputes surrounding these topics have been permanent throughout the XX century. A point of view of a couple of professional historians, that we review only as an example, dedicated to examining the characteristics of the Inca State and the indicated hypothesis are those by the tireless María Rostworowski, whose research extends for almost half a century and it unveils with Pachacutec Inca Yupanqui in 1953, and John Murra whose doctoral thesis in Ethnology (University of Chicago 1955) was published with the title The Economic organization of the Inca State, book that was accompanied by The political and economic formations of the Andean State (MURRA, 1975, 1978).

In Colombia, the debate was known at the beginning of the sixties, specially the writings of Anteo Quimbaya, Francisco Posada or the Study Circle of Anteo Quimbaya, to mention some authors, who tried to respond the question for the character of pre-Hispanic and colonial society (POSADA, ROSSO and DE SANTIS, 1965?; CENTRO DE ESTUDIOS ANTEO QUIMBAYA, 1973; BUENAVENTURA, QUIMBAYA, ROMUALDOVICH GRIGULEVIC, POSADA-DÍAZ, RESTREPO, 1960). These short texts have certain qualities that we have to highlight: they

${ }^{31}$ An important compilation of articles gave rise to the book by Carlos Sempat Assadourian, Ciro Flamarión Santana Cardoso, Horacio Ciafardini, Juan Carlos Garavaglia y Ernesto Laclau, Modos de producción en América Latina (SEMPAT ASSADOURIAN, 1973).

32 (HAYA DE LA TORRE, 1927) and Anti-imperialism and APRA was first developed in 1928 as part of a controversy with José Antonio Mella and then published in 1935, although, but cannot circulate for various reasons (HAYA DE LA TORRE, 2010); Luis Valcárcel, Tempest in the Andes was originally released in 1928 thanks to the support of Mariátegui (VARCARCEL, 1972); and José Carlos Mariátegui, Seven essays on the interpretation of Peruvian reality (MARIÁTEGUI,1928). 
strived to elaborate a Marxist approach about pre-Hispanic societies that lived in the current Colombia; they pretended to develop reflections that would explain a period in the history of Colombia, and in this sense its contribution to the development of social sciences is unobjectionable; the texts were considered university booklets and had ample use; and finally, the short works were recognized by the Latin American criticism.

By the decade of the eighties and nineties the use of Marx and The Capital was abandoned in the Colombian university environment. The existing seminars in the economy and social sciences faculties were substituted by mathematics and statistics, and the specialized publications tended to disappear. Besides, the supremacy of war, the disintegration of the Soviet Union, the boom of post-modernism and of thinking currents of opinion that advocated for the end of ideologies weakened even more the possibilities of a Marxist thought. However, recent local and international changes have placed The Capital in the scene of academic debates. We still do not know how the new generations will work with Marx.

Finally, we would have to consider as part of The Capital's appropriations the readings through the mediation of some authors like Louis Althusser. In effect, Latin America saw in the sixties and seventies the circulation of a variety of Marxism that were characterized by a renovation of debates and the utilization of not well-known academics, among them Gramsci and Althusser, to redefine approaches to the cultural fact or the debate about Marx's method. Althusser was important because he was one of the architects of reflection from the structuralist point of view of Marx's work, the formed various generations of philosophers from several parts of the world and he proposed a series of controversies which were copied in various places. His work Lire le capital and Pour Marx, both from 1965, were rapidly translated to Spanish by Siglo XXI (ALTHUSSER, 1967, 1969); there was a small group of Latin American intellectuals who worked directly with the French philosopher, as was the case of Chilean Martha Harnecker and Mexican Fernanda Navarro. Harnecker became one of the academics who introduced the French author into Latin America and was concerned with spreading Marx's thinking through booklets, her work, Elemental concepts of historic materialism, published in 1968, reaches more than sixty editions (HARNECKER, 1968). Years later she produced another booklet, The Capital fundamental concepts (1971) to serve as guide for readers that for the first time explored Marx.33 On her part, Navarro published the text

33 The booklets were very popular in the sixties and seventies. However, they seem little appropriate because generally they have the effect of "avoiding" a direct encounter with the author. We obviously recognize the enormous political and cultural impact of these works, its permanent re-edition speaks of the existence of society's need. (HARNECKER, 1971), electronic version in http://www.rebelion.org/docs/88241.pdf 
Philosophy and Marxism. Interview of L. Althusser; and various intellectuals from the continent used both works mentioned as part of the renewal of the reading of Marx and The Capital.34 Thanks to this work, Fernanda Navarro has traveled to the most important universities of the world giving lectures round what she considers the last Althusser and organizing international congresses in homage to the French philosopher. 35

In Colombia, the circulation of Gramsci or Althusser was comparatively lower than in other countries. However, Gramsci was employed more in the renovation projects of the left in the nineties, when it was the ideological base to create new political organizations, which they did not manage to consolidate.

\section{Final Comments}

In our continent protest movements were known which incorporated several readings of social utopia and for this since the middle of the XX century the concepts of socialism and communism circulated. As in other parts of the world, the appropriations of the concepts and utopia depended on the conditions of the cultural and political local universe. In Latin America there was a strong conservative reaction and of the Catholic Church that fed a visceral anti-communism which closed every space to the circulation of authors like Marx.

Despite this environment at the end of the XIX century there took place one of the first translations in Castilian of The Capital. Such work, with all the limitations that can be pointed, was a milestone in political and cultural history of the continent. Later, and because of diverse reasons of local and world order, among which we find the actioning of intellectual and political webs of Mexican and Argentinian anarchists, the impact of the Mexican Revolution, the Spanish exile and then the exile of southAmerican and central-American academics that stimulated a more academic position, a reflection by the social scientists of the region. In this sense the complete translation of The Capital done by Wenceslao Roses

\footnotetext{
34 Fernanda Navarro, Filosofía y marxismo. Entrevista a L. Althusser (NAVARRO, 1988). This work was later translated into Japanese in 1993, French into 1994, English into 1998, Italian into 2003, and Chinese into 2012.

35 In 2012 we organized with Ana Popovich an international congress about the presence of Althusser in Latin America which had the participation of Fernanda Navarro. In the present year the memoirs of the event were published. For lack of space we will not extend in the references to the studies about the impact of Althusser in Latin America, but we would have to consider the work of the Chilean magazine Demarcaciones and the recent editions of the texts of Marcelo Starcerbaum.
} 
constituted a major event which transformed various generations of critical intellectuals.

The placement of problems and inconsistencies in Roses' work and a better knowledge of Marx's work created the need of translations that were truer to the original and for these editions of Siglo XXI and Grijalbo appeared. This work was also required by the world of universities that demanded booklets and works of academic rigor.

The critical appropriation of The Capital stimulated a series of important reflections about capitalism, the method and the concepts elaborated by Marx and a long series of topics. In countries like Mexico and Colombia the presence of The Capital is indispensable to understand the development of disciplines as economy, philosophy, anthropology and history, especially in the sixties and seventies.

It is necessary to highlight that what we have denominated appropriation did not constitute a passive act or a copy of Marx's work. In the first place since every reading is a transforming experience from the author and the reader, it assumes a varied set of practices which influence reflection from concrete historic conditions, life experiences, situation of social sciences, degree of development of leftist political movements, conditions of university life and, of course, the political and economic features of each nation and the continent. To "overcome" the work of Marx indicating that it is about someone who did not think of the colonial situation, which is part of western epistemes and therefore is racist, colonialist and imperialist and that it is not useful from the principle of enunciation, results solely possible by an offensive of rightist thinking with an evident tint of anti-communism. The Decolonial Turn, that unfortunately has become an intellectual trend and that has installed itself in the nets of academic consecration from where it pontificates what is critical and radical, constitutes a variant of post-modern clearly antiMarxist postures. This current has gained force due to the negative impact of post-modernism in social sciences and humanities and especially due to a profound ignorance of history, particularly of intellectual and cultural history of our continent, which some of its spokespeople exhibit. Despite these limitations, there has been a renewal of Marxist criticism due to the crisis of the neoliberal model, the rise of the social struggle and the production of new research on the 150th anniversary of the publication of Capital.

\section{Bibliography}


AGUILERA, Mario y VEGA, Renán. Ideal democrático y revuelta popular. Bosquejo histórico de la mentalidad política popular en Colombia 17811948. Bogotá: CEREC, Universidad Nacional, IEPRI, 1991.

ALTHUSSER. Louis. La revolución teórica de Marx. México: Siglo XXI, 1967.

. Para leer El capital. México: Siglo XXI, 1969.

ASTARITA, Rolando. en https://rolandoastarita.blog/2012/o9/13/traducciones-de-el-capital-y-unerror-en-siglo-xxi/>.

ARICÓ, José. La cola del diablo: itinerario de Gramsci en América Latina. Buenos Aires: Sigo XXI Editores, 2005.

BAUTISTA, Juan José. ¿Que significa pensar desde América Latina? Barcelona: Akal, 2014.

BERNSTEIN, Harry. Marxismo en México, 1917-1925. Historia Mexicana, VII, 4, 28, abril-junio de 1958, pp. 497 y ss.

BRAVO GIAN, Mario. Historia del socialismo 1789-1848. El pensamiento socialista antes de Marx. Barcelona: Ariel, 1971.

BOSTEELS, Bruno. Marx and Freud in Latin America. London: Verso Books, 2012.

BUENAVENTURA, Nicolás et al. Interpretación marxista de la sociedad colombiana del siglo XVII al siglo XX. Bogotá: Los Comuneros, 1960.

CASTRO-GÓMEZ, Santiago; GROSFOGUEL, Ramón. Prologo. El giro decolonial, teoría crítica y pensamiento heterárquico. In: CASTROGÓMEZ, Santiago; GROSFOGUEL, Ramón. El giro decolonial. Reflexiones para una diversidad epistémica más allá del capitalismo global. Bogotá: Siglo El Hombre Editores, IESCO-Universidad Centra, Instituto Pensar, Pontificia Universidad Javeriana, 2007.

CENTRO DE ESTUDIOS ANTEO QUIMBAYA. Formación del capitalismo en Colombia. Bogotá: Ediciones Armadillo, 1973.

CORREA MERLASSIMO, Victoria. Analysis of three differetnt Spanish traslations of Karl Marx's Das Kapital (1867): Juan B. Justo (1898), Wenceslao Roces (1946), Pedro Scaron (1975). Departament of History of Economic Thought- University of Barcelona, Barcelona, versión electronica: $\quad<$ https://eet.pixelonline.org/files/research_papers/SP/Analysis\%20of\%20Three\%20Differe nt\%20Spanish\%20Translations\%20of\%20Karl\%20Marx_S\%20Das\%20K apital.pdf $>$.

DE ARAGÓN, Miryam. Adolfo Sánchez Vásquez: Las ideas estéticas de Marx. Ideas Valores, Bogotá, n. 30-31, 1968, pp. 91-2.

DUSSEL, Enrique. La producción teórica de Marx. Caracas: Fondo Editorial El Perro y la Rana, 1985a. 
- La producción teórica de Marx. Una introducción a los Grundrisse. México: Ediciones Siglo XXI, 1985b.

. Hacia un Marx desconocido. Un comentario de los Manuscritos

del 61-63. México: Ediciones Siglo XXI en coedición con UAM-I, 1988.

. Las metáforas teológicas de Marx. Estella (Navarra): Editorial

Verbo Divino, 1993.

. El último Marx (1863-1882) y la liberación latinoamericana.

México: Ediciones Siglo XXI, 1990.

. Marx y la modernidad. Conferencias de La Paz. La Paz: Rincón

Ediciones, 2008.

EL SOCIALISTA. El amigo del pueblo. 29 de enero de 1852, Bogotá, p. 1.

EL TRIMESTRE ECONÓMICO. Plan de estudios de la Escuela Nacional de Economía. México, v. 13, n. 49, 1, abril-junio de 1946, pp. 175-177.

ELDROPEITO, La republicas hispanoamericanas y el socialismo. Bogotá: reimpreso por Nicolás Gómez, 26 de enero de 1852, Biblioteca Nacional de Colombia, Fondo Pineda 224, p. 8.

ESTRELLA, Alejandro. El exilio y la filosofía marxista. El caso de Wenceslao Roses. En: ILLADES, Carlos (Coord.). Camaradas. Nueva historia del comunismo en México. México: Secretaría de Cultura, Fondo de Cultura Económica, 2017, pp. 205 y ss.

FACULTAD DE CIENCIAS ECONÓMICAS, Universidad Nacional de Colombia. Proyecto educativo de programa, autoevaluación y seguimiento de la calidad de los programas de pregrado, Economía. Bogotá, Universidad Nacional. 2014. En: <http://www.pregrado.unal.edu.co/docs/pep/pep_2_24.pdf >.

GANDLER, Stefan. Marxismo crítico en México: Adolfo Sánchez Vázquez y Bolívar Echeverría. México, D.F., Fondo de Cultura Económica/Universidad Nacional Autónoma de México/Universidad Autónoma de Querétaro, 2007.

GARCÍA CORNEJO, Héctor. Experiencia y discurso en la vuelta de siglo. La crítica de la modernidad en la obra de Bolívar Echeverría. Morelia: Instituto de Investigaciones Filosóficas, Doctorado en Filosofía, Universidad Michoacana de San Nicolás de Hidalgo, 2018.

GUADARRAMA GONZÁLEZ, Pablo. Bosquejo histórico del marxismo en América Latina. En: Despojado de todo fetiche. Autenticidad del pensamiento marxista en América Latina. Bogotá: Universidad INCCA de Colombia, Universidad Central de Las Villas, 1999.

HARNECKER, Martha. Los conceptos elementales del materialismo histórico. México: Siglo XXI Editores, 1968.

El capital: conceptos fundamentales. En

<http://www.rebelion.org/docs/88241.pdf>. 
HAYA DE LA TORRE, Víctor Raúl. Por la emancipación de América Latina. Buenos Aires: M. Gleizer Editor, 1927.

El antiimperialismo y el Apra. Lima: Fondo Editorial del Congreso del Perú, 2010.

HOBSBAWM, Eric. Labouring Men: Studies in the History of Labour. Londres: Weindenfeld and Nicolson, 1964.

ILLADES, Carlos. Las otras ideas: estudios sobre el primer socialismo en México, 1850-1935. México: Era, 2008.

Océano, 2018.

. El futuro es nuestro. Historia de la izquierda en México. México:

LA REVOLUCIÓN. Orijen, progresos, fines $i$ estado actual de la revolución democrática, que se prepara en esta ciudad. Bogotá: Imprenta F. T. Amaya, 1858.

LOAIZA CANO, Gilberto. Del débil utopismo de las élites a la formación de una cultura política popular en Colombia. En: ILLADES, Carlos and SCHELCHKOV, Andrey (Coord.). Mundos posibles. El primer socialismo en Europa y América Latina. México: El Colegio de México, Universidad Autónoma Metropolitana-Cuajimalpa, 2014, pp. 189 y ss.

LOMNITZ, Claudio. El regreso del camarada Ricardo Flores Magón. México: Era, 2018.

LÖWY, Michael. El marxismo en América Latina del 1909 a nuestros días (Antología). México: Ediciones Era, 1980.

MADIEDO, Manuel María. La ciencia social, o el socialismo filosófico, derivación de las grandes armonías del cristianismo. Bogotá: Impreso por Nicolás Pontón, 1853.

MARIÁTEGUI, José Carlos. Siete ensayos de interpretación de la realidad peruana. Lima: Biblioteca Amauta, 1928.

MARX, Carlos and ENGELS, Federico. El manifiesto comunista. En: <https://www.bcn.cl/obtienearchivo?id=documentos/10221.1/19671/1/19 742.pdf $>$.

MAURO MARINI, Ruy y MILLÁN, Márgara (Coord.). La teoría social latinoamericana. Textos escogidos. Tomo III la centralidad del marxismo. México: Facultad de Ciencias Políticas y Sociales, Coordinación de Estudios Latinoamericanos, UNAM, 1995.

MAZADE, Carlos. El socialismo en la América del Sur. Bogotá: Impreso por Espinosa, 1852.

MURRA, John. Las formaciones económicas y políticas del mundo andino. Lima: Instituto de Estudios Peruanos, 1975.

. La organización económica del Estado Inca. México: Siglo XXI Editores, 1978.

NAVARRO, Fernanda. Filosofía y marxismo. Entrevista a L. Althusser. México: Siglo XXI, 1988. 
ORTIZ, Venancio. Historia de la revolución del 17 de abril de 1854. Bogotá: Imprenta de Francisco Torres Amaya, 1855.

PAGNI, Andrea (ed.). El exilio republicano español en México y Argentina. Historia cultural, instituciones literarias, medios. Madrid: Iberoamericana / Frankfurt am Main, Vervuert / México D. F., Bonilla Artiga Editores, 2011.

PANIAGUA, Javier. Breve historia del socialismo y del comunismo. Madrid: Ediciones Nowtilus, 2010.

POSADA, Francisco José Rosso and DE SANTIS, José. Ensayo marxista sobre la sociedad Chibcha. Bogotá: Ediciones Los Comuneros, S.F., [1965?].

RIBAS, Pedro. La primera traducción castellana de El capital (18861887). Cuadernos Hispanoamericanos, 420, Madrid, junio de1985.

RIVERA MIR, Sebastián. Editorial Popular y la unidad bajo costo: libros y folletos comunistas en el México cardenista. In: ILLADES, Carlos (Coord.). Camaradas. Nueva historia del comunismo en México. México: Secretaría de Cultura, Fondo de Cultura Económica, 2017, pp. 171 y ss.

SANCHEZ VÁZQUEZ, Adolfo. Ideas estéticas en los Manuscritos económicos-filosóficos de Marx. Diánoia, México, v. 7, n. 7, 1961, pp. 236 y ss.

. Las ideas estéticas de Marx. México: Biblioteca Era, 1965.

- La filosofía de la praxis. México: Grijalbo, 1967.

. Conferencia El marxismo en América Latina. Dialéctica, n. 19,

1988, versión electrónica en <http://marxismoyrevolucion.org/wpcontent/uploads/2016/o6/El-marxismo-en-Am\%C3\%A9rica-Latina.pdf $>$. SANTOS, Boaventura S. and MENESES, María (eds.). Epistemologías del sur (perspectivas). Madrid: Akal, 2014.

SCARON, Pedro. Estudio preliminar. En: MARX, Carlos. El capital, crítica de la economía política (Traducción, edición, notas y advertencia de Pedro Scaron). Madrid: Siglo XXI, 2017.

SEMPAT ASSADOURIAN, Carlos et al. Modos de producción en América Latina. Córdoba: Cuadernos Pasado y Presente n. 40, 1973.

SUPELANO-GROSS, Claudia. El retorno de lo reprimido en Colombia: marxismo y psicoanálisis. Teoría y Crítica de la Psicología, 7 (2016), pp. 213-220, p. 214.

TARCUS, Horacio. El marxismo olvidado en la argentina: Silvio Frondizi y Milciades Peña. Buenos Aires: Ediciones el Cielo por Asalto, 1996. - Marx en la Argentina. Sus primeros lectores obreros, intelectuales y científicos. Buenos Aires: Siglo XXI Editores, 2007. . El socialismo romántico en el Río de La Plata (1837-1852).

Buenos Aires, Fondo de Cultura Económica, 2016. 
A 150 años de El capital. Peripecias políticas de las primeras traducciones al español. Nueva Sociedad, n. 270, julio-agosto de 2017. THOMPSON, E. P. La formación de la clase obrera en Inglaterra. Barcelona: Crítica, 1989.

TRADUCCIONES de El capital al castellano. En: <http://seguiiltuocorsoelasciadirlegenti.blogspot.com.co/2011/10/lastraducciones-de-el-capital-al.html>.

URREGO, Miguel Ángel. Intelectuales, estado y nación en Colombia. De la guerra de los Mil Días a la constitución de 1991. Bogotá: DIUC, 1997.

VARCÁRCEL, Luis. Tempestad en los Andes. Lima: Editorial Universo 1972.

VARGAS LOZANO, Gabriel (Ed.). En torno a la obra de Adolfo Sánchez Vázquez (filosofía, ética, estética y política). México: Facultad de Filosofía y Letras, UNAM, 1995.

VOZ DIGITAL. El Partido Comunista Colombiano y la cultura. Bogotá, 15 julio, 2016, <http://semanariovoz.com/el-partido-comunista-colombianoy-la-cultura/ $>$.

ZULETA PARDO, Mónica. La voluntad de verdad en Colombia: una genealogía de las ciencias sociales profesionales. Bogotá: Universidad Central, 2011.

ZULETA, Estanislao. Ensayos sobre Marx. Medellín: Editorial Percepción, 1987.

Como citar:

URREGO, Miguel Ángel. The capital of Karl Marx, Marxism and the Latin American intellectuals: the cases of Mexico and Colombia. Verinotio Revista on-line de Filosofia e Ciências Humanas, Rio das Ostras, v. 25, n. 1, pp. 186-209, abr. 2019.

Data de envio: 8 ago. 2018

Data de aceite: 15 jan. 2019 